Zeszyty Naukowe Szkoły Głównej Gospodarstwa Wiejskiego w Warszawie

Problemy Rolnictwa Światowego tom 18 (XXXIII), zeszyt 2, 2018: 140-148

DOI: $10.22630 /$ PRS.2018.18.2.41

Filip Kłobukowski $^{1}$, Maria Śmiechowska ${ }^{2}$, Magdalena Skotnicka ${ }^{3}$

${ }^{1,3}$ Gdański Uniwersytet Medyczny

${ }^{2}$ Akademia Morska w Gdyni

\title{
Możliwości wykorzystania karobu (Ceratonia siliqua) w sektorze żywnościowym i żywieniowym
}

\section{Possibilities of Utilizing Carob (Ceratonia Siliqua) in Food Industry and Nutrition}

\begin{abstract}
Synopsis: Proszek pozyskiwany z nasion karobowych, zwany inaczej mączką chleba świętojańskiego, ma szerokie zastosowanie przemysłowe. Spełnia funkcję zagęstnika, stabilizatora, w odpowiednich warunkach substancji żelującej oraz nośnika. Wielu konsumentów ocenia karob jako produkt, który ze względu na swój smak i aromat może niejednokrotnie stanowić substytut kakao. W klimacie śródziemnomorskim, gdzie występuje karob, mączka chleba świętojańskiego stanowi główny surowiec do produkcji słodyczy. Celem tej pracy było wskazanie możliwości wykorzystania karobu jako dodatku o działaniu prozdrowotnym i tym samym potencjalnym składniku funkcjonalnym w żywności (o znaczeniu innym niż technologiczne bądź sensoryczne).
\end{abstract}

Słowa kluczowe: karob, kakao, zastosowanie, wartość odżywcza, guma karobowa

\begin{abstract}
Carob flour is produced from carob seeds and can be widely utilized in the food industry. It is mainly used as a thickener or stabilizer, and in certain conditions can have gel-forming abilities and is used as a medium (mainly for flavour). Many consumers consider carob flour as a cocoa substitute thanks to its flavour and aroma. In Mediterranean climates, which is the carob's natural growth environment, carob flour is utilized in sweets production. The aim of this study was to point out possibilities of utilizing carob as a product that is beneficial to health, which should therefore be considered as a valuable resource in producing functional food.
\end{abstract}

Key words: carob, cocoa, application, nutritional value, carob gum

JEL Classification: I15, Q11

\section{Wprowadzenie}

Karob jest rośliną uprawianą już przeszło 2000 lat, jednakże jest on produktem stosunkowo słabo znanym wśród polskich konsumentów. Wynika to głównie ze względu na nieliczne informacje, które można znaleźć na jego temat i niską dostępność owego produktu. Znaleźć go można właściwie jedynie w sklepach z żywnością ekologiczną, sprzedawanego $\mathrm{w}$ formie proszku.

Ze względu na szereg właściwości wykorzystywany jest w przetwórstwie żywności oraz przemyśle farmaceutycznym i kosmetycznym (Durazzo i in., 2014). Produkt ten

${ }^{1}$ mgr inż., Zakład Towaroznawstwa Żywności GUMed, ul. Dębinki 7, 80-211 Gdańsk, e-mail: fklobukowski@gumed.edu.pl

${ }^{2}$ prof. dr hab., Katedra Towaroznawstwa i Zarządzania Jakością AM w Gdyni, ul. Morska 81-87, 81-225 Gdynia

3 dr inż., Zakład Towaroznawstwa Żywności GUMed, ul. Dębinki 7, 80-211 Gdańsk 
charakteryzuje się unikalnymi właściwościami organoleptycznymi, dzięki czemu mógłby znaleźć szersze zastosowanie na naszym rynku. Wielu autorów wskazuje, że produkty karobowe ze względu na walory organoleptyczne, przypominają często produkty czekoladowe i w niektórych regionach świata zastępują słodycze (Mitka i in., 2007; Biner $i$ in., 2007). Ponadto, karob charakteryzuje się bardzo korzystnym składem związków bioaktywnych, dzięki czemu mógłby stanowić wartościowe urozmaicenie i wzbogacenie diety, z niezaprzeczalną funkcją prozdrowotną (Mitka i in., 2007).

\section{Charakterystyka karobu}

Drzewo karobowe (Ceratonia siliqua L.) jest wiecznie zielonym drzewem, należącym do bobowatych. Rośnie w klimacie śródziemnomorskim, gdzie jest uprawiany oraz występuje jako „dziko rosnąca” roślina. Pochodzi najprawdopodobniej z Syrii i Arabii. Jego uprawą zajmowali się Grecy, o czym świadczą podobizny karobu na freskach pompejskich. Produkcja roczna wynosi ok. 310000 ton, a głównymi producentami sa Hiszpania, Włochy, Portugalia, Maroko, Grecja, Cypr, Algieria i Tunezja (Benković i in., 2017; Biernacka i in., 2017). Ogromną zaletą karobu jest jego wysoka odporność na susze oraz unikalne cechy organoleptyczne.

Szarańczyn strąkowy (karob) może dorastać aż do 15 metrów., natomiast jego liście są wiecznie zielone, pierzaste i skórzaste. Drzewo jest bardzo wytrzymałe na warunki klimatyczne i potrafi przetrwać aż do 200 lat. Owoce to płaskie, jadalne strąki o długości blisko $25 \mathrm{~cm}$, o barwie brązowofioletowej, nazywane chlebem świętojańskim. Zbiory z jednego sezonu mogą dochodzić nawet do 1 tony owoców. W pojedynczym strąku może się znajdować 15 nasion. Strąki zrywa się nie w pełni dojrzałe, po czym suszy się je na słońcu. Same strąki charakteryzują się niezbyt przyjemnym zapachem, a jadalne strąki nie stanowią atrakcyjnego pokarmu, gdyż są bardzo twarde i należy je długo rzuć, by poczuć przyjemny słodki smak (Mitka i in., 2007).

Karob wykorzystywany jest głównie w formie proszku, który zwany jest mączką chleba świętojańskiego. Pozyskiwany jest on poprzez zmielenie uprażonych nasion wydzielonych ze strąków. Nasiona składają się w $30-33 \%$ z łupiny, w $23-25 \%$ z zarodka oraz w $42-46 \%$ z endospermy. Największym problemem jest odseparowanie lupinek od pozostałej części nasion. Dokonuje się tego dwoma metodami: w procesie kwaśnym i tradycyjnie. Pierwsza metoda polega na oddziaływaniu rozcieńczonym kwasem siarkowym, w podwyższonej temperaturze, przez co strąki ulegają zwęgleniu. Następnie maszyny myjące i szczotkujące usuwają łupiny, a nasiona poddawane zostają suszeniu. W metodzie tradycyjnej, zwanej rusztową, strąki są prażone w piecu obrotowym, dzięki czemu łupiny zostają oddzielone od nasion. Tak pozyskany produkt charakteryzuje się ciemniejszym zabarwieniem, ale nie używa się przy nim kwasu siarkowego, dzięki czemu nie wymaga on dodatkowego mycia (Mitka i in., 2007). Mączka chleba świętojańskiego stanowi dodatek do żywności oznaczony symbolem E410.

\section{Skład karobu}

Głównym składnikiem karobu są węglowodany. Ich zawartość waha się w granicach 40-60\%. Najważniejszym przedstawicielem tej grupy w mączce karobowej jest sacharoza 
(32-38\%). Glukoza i fruktoza stanowią odpowiednio 5-7\% i 5-6\%. Dodatkowo mączka karobowa zawiera znaczną ilość błonnika pokarmowego (27-50\%). Bardzo liczną grupę związków aktywnych stanowią polifenole. Ich zawartość w ziarnie kakaowym wynosi aż 18-20\%. Zawartość białka wynosi 3-6\%, w skład których wchodzą albuminy, globuliny, prolaminy i gluteliny. Popiół stanowi niecałe $1,2 \%$. Karob zawiera również witaminy A, $\mathrm{B}_{2}, \mathrm{~B}_{3}, \mathrm{D}$ oraz składniki mineralne takie jak: wapń, fosfor, potas, magnez i żelazo, a ponadto mangan, bar, miedź oraz nikiel. Tłuszcz w karobie stanowi zaledwie 0,4-0,8\% (Mitka i in., 2007; S $\square$ czyk i in., 2016; Benković i in., 2017; Rtibi i in., 2017).

Przede wszystkim ze względów zdrowotnych, ogromne zainteresowanie wzbudza bardzo liczna grupa związków przeciwutleniających. W składzie antyoksydantów mączki chleba świętojańskiego, zidentyfikowano głównie proantocyjanidyny, flawan-3-ole, kwas galusowy, (+)-katechinę, (-)-galusan epikatechiny, (-)-galusan epigalokatechiny oraz glikozydy kwercytyny. W strąkach stwierdzono ponadto galotaniny i elagotaniny (Rtibi i in. 2017). Owen i in. zidentyfikowali także kwas kumarowy i cynamonowy (Owen i in. 2003).

\section{Wykorzystanie karobu w przemyśle spożywczym}

Mączka chleba świętojańskiego stanowi wykorzystywany w przemyśle dodatek do żywności E410. Ze względu na swoje cechy pełni rozmaite funkcje. Nie stanowi on barwnika ani substancji słodzącej, zatem można go wykorzystywać w ilościach quantum satis, a jedynymi ograniczeniami jest brak możliwości stosowania do wyrobów cukierniczych w żelowych minikubeczkach bądź w produktach odwodnionych, przeznaczonych do ponownego uwodnienia (Rozporządzenie Ministra Zdrowia, 2010). Guma karobowa jest wrażliwa na działanie enzymów i substancji utleniających, jest nietoksyczna oraz łatwo ulega biodegradacji. Dzięki czemu nie określa się dla niego dopuszczalnego dziennego spożycia (ADI). Mączka chleba świętojańskiego wykorzystywana jest głównie jako zagęstnik, stabilizator, substancja żelująca (w odpowiednich warunkach) i ze względu na jego smak, by kształtować cechy sensoryczne produktu. Stosowany jest między innymi do produkcji lodów, zup, słodyczy, wypieków, jogurtów (Mitka i in., 2007; Sęczyk i in., 2016).

W praktyce konsumenckiej, rzadko występującej w Polsce, sporządza się napój na bazie mączki karobowej. Mączka chleba świętojańskiego dobrze rozpuszcza się w gorącej wodzie (o temp. $>80^{\circ} \mathrm{C}$ ), mleku roztworach soli i cukru, natomiast nie sprawdza się wykorzystanie zimnej wody, etanolu bądź innych organicznych rozpuszczalników. Po rozpuszczeniu w gorącej wodzie $\left(\mathrm{t}>95^{\circ} \mathrm{C}\right)$ tworzy roztwory o dużej lepkości, która utrzymuje się po ochłodzeniu i jest odporna na zmiany $\mathrm{pH}$. Natomiast w przypadku środowiska silnie kwaśnego, o pH poniżej 3, ulega hydrolizie (Mitka i in., 2007). Istotnym jest fakt, iż roztwory z dodatkiem mączki karobowej nie tworzą żeli, jednakże stwierdzono pewne synergistyczne oddziaływanie $\mathrm{z}$ ksantanem, $\mathrm{K}$-karagenem oraz agarem. Odpowiednio, uzyskuje się silny żel, termicznie odwracalny, żel zbliżony do żelatynowego, żel nie wykazujący synerezy, o zwiększonej elastyczności (Mitka i in., 2007).

Sok wyciskany ze strąków (kaftan) służy do produkcji alkoholu, natomiast z miąższu strąków szarańczynu uzyskuje się mąkę do wypieku chleba oraz ciastek. W praktyce, w regionach, gdzie karob występuje naturalnie najczęściej stanowi on roślinę pastewną, jednakże gdzieniegdzie stanowi on pewną rezerwę żywności, na wypadek czasów głodu (Mitka i in., 2007). 


\section{Karob i jego potencjalne zastosowanie}

Pomijając funkcje technologiczne, karob charakteryzuje się unikalnymi cechami organoleptycznymi. Najistotniejszą zaletą jest jego smak, który przypomina osłodzone kakao. Z wykorzystaniem tej cechy wiązać się może jedno z bardziej wartościowych potencjalnych zastosowań szarańczynu.

Ze względu na coraz trudniejsze warunki uprawy w większości regionów świata, wielu producentów szuka produktów, które będą mogły z powodzeniem zastępować (pod kątem technologicznym bądź organoleptycznym) znane dotychczas środki spożywcze. Najbardziej zagrożone są uprawy, które charakteryzują się wysokimi wymogami agrotechnicznymi i/lub klimatycznymi. Do tego typu upraw można zaliczyć plantacje kakao. Dodatkowo, regiony w których uprawiane jest kakao, charakteryzują się w większości niestabilną sytuacją polityczną i społeczną. Prowadzi to do szeregu konsekwencji, w tym ekonomicznych, do których zaliczyć można dodatkowe wahania podaży, przy niespadającym popycie. Mając na względzie nadmienione czynniki, poszukuje się alternatywy dla kakao. W przypadku wielu produktów sugeruje się, że rozwiązanie może stanowić wykorzystanie karobu.

Kakao cenione jest przez konsumentów ze względu na swój smak i zapach, którego można doświadczać w ciastach i ciastkach, napojach i czekoladach. Najcenniejszy składnik kakao i zarazem nośnik smaku i aromatu, to thuszcz, popularnie zwany masłem kakaowym. Stanowi on główny składnik czekolady, ale także wykorzystywany jest np. w kosmetykach. Ze względu na wysoką wartość tłuszczu kakaowego, stale poszukuje się jego zamienników. Zgodnie z Dyrektywą 2000/36/WE Parlamentu Europejskiego i Rady z dnia 23 czerwca 2000 r. odnosząca się do wyrobów kakaowych i czekoladowych przeznaczonych do spożycia przez ludzi, dopuszcza się dodatek tłuszczów roślinnych innych niż masło kakaowe (illipe, olej palmowy, sal, masłosz, kokum guargi, ziarno owocu mango) (PN-EN ISO 23275-1_2009P). Nie może być on jednak większy niż 5\% masy gotowego produktu ,po odjęciu od wagi łącznej jakiejkolwiek innej substancji jadalnej, użytej zgodnie z załącznikiem I B, bez ograniczania minimalnej zawartości masła kakaowego lub suchej masy kakaowej łącznie" (DYREKTYWA 2000/36/WE 2000). Należy przy tym pamiętać, że producent wykorzystujący zamienniki tłuszczu kakaowego winien umieścić taką informację na opakowaniu. Niejednokrotnie jednak, owej informacji brakuje na etykietach, co stanowi zafałszowanie produktu (Kowalska i in. 2008; UOKiK 2010). $\mathrm{W}$ wielu aspektach organoleptycznych karob z powodzeniem zastępuje kakao, być może pozwoli to zmodyfikować także recepturę, by uzyskać produkt o zbliżonych cechach sensorycznych do czekolady, jednak w znacznie niższej cenie.

Kolejnym argumentem, który przemawia za coraz szerszym zastosowaniem karobu jest jego potencjalna podaż. Jego zdecydowanie niższe wymagania klimatyczne i agrotechniczne oraz wysoka odporność na susze, pozwalają sądzić, że produkcja chlebka świętojańskiego nie będzie trudna. W miejscach jego naturalnego występowania można napotkać drzewa karobowe rosnące „dziko”, czyli bez żadnego wspomagania przez ludzi. Wartym uwagi jest także fakt, iż produkcja i przetwórstwo karobu charakteryzuje się bardzo niskim odsetkiem odpadów. W praktyce przemysłowej i badawczej wykorzystuje się niemalże wszystkie części drzewa - liście, strąki, nasiona. Ponadto, dzięki niskim wymogom, uprawa szarańczynu mogłaby znacznie wzrosnąć w obliczu większego popytu. Niestety, w przypadku kakao areał się zmniejsza bądź wykorzystuje się mniej szlachetne odmiany o niższych wymaganiach. Dodatkowo, kakao mimo występowania w klimacie tropikalnym wymaga stosunkowo dużo cienia, ponadto jest wrażliwe na silne wiatry. Mając na względzie wszystkie czynniki uprawy, ziarno kakaowe posiada 


\section{Ktobukowski F., Śmiechowska M., Skotnicka M.}

wysoką cenę oraz jej wysokie wahania. Występują one zarówno na przestrzeni lat jak i w przypadku danej pory roku (rys. 1). W roczniku statystycznym brak informacji dotyczącej ceny tony ziarna karobowego, jednakże ceny produktu finalnego (proszku) są porównywalne i niższe od proszku kakaowego.

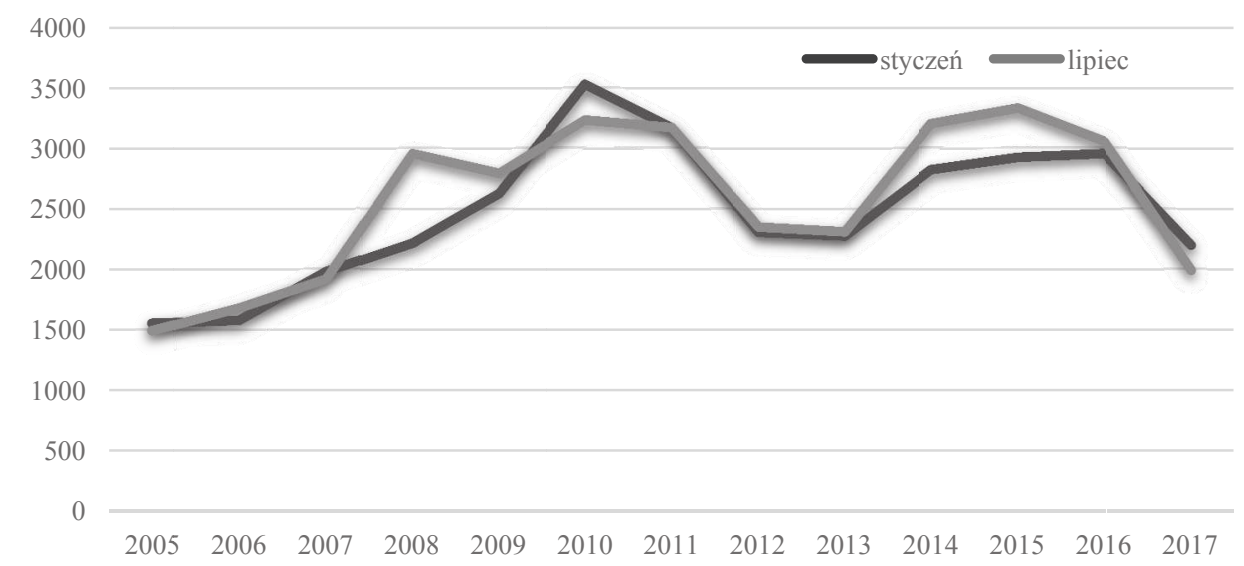

Rys. 1. Zmiany ceny ziarna kakaowego w latach 2005-2017 (USD/t)

Fig. 1. Cocoa bean price changes in years 2005-2017 (USD/ton)

Źródło: opracowanie własne na podstawie: https://www.icco.org/.

Mączka szarańczynu może zostać wykorzystana jako dodatkowy składnik do produktów mącznych. Przykładowo, Sęczyk, Świeca i Gawlik-Dziki (2016) wykorzystali dodatek E 410 do produkcji makaronu z semoliny, po czym poddali go analizie sensorycznej oraz wartości odżywczej. Parametry obu kryteriów były wyżej ocenione niż produkt kontrolny (S $\square$ czyk $\mathrm{i}$ in., 2016). Z kolei, Albertos $\mathrm{i}$ in. zaproponowali wykorzystanie łupiny nasion karobowych. Stwierdzili oni, że dodatek zaledwie 1\% zmielonych łupin do rozdrobnionej makreli jest w stanie skutecznie spowalniać procesy oksydacji tłuszczów i białek (Albertos i in., 2015).

Gravador i in. (2015) zbadali jaki wpływ będzie miało spożywanie przez jagnięta diety wzbogaconej w pulpę karobową. Celem doświadczenia było sprawdzenie czy zmodyfikowana dieta przyczyni się do zwiększonej ilości wielonienasyconych kwasów tłuszczowych (PUFA) w mięśniach i jak owe zmiany wpłyną na stabilność oksydacyjną tłuszczów. Wyniki wykazały niezmienioną stabilność oksydacyjną przy jednoczesnym wzroście zawartości PUFA. Gravador i inni (2015) przeprowadzili badanie na młodych gęsiach, których zmodyfikowana dieta nie przyczyniła się do wzrostu zawartości tłuszczu ogółem (zawartość pulpy 24-35\%), a przy wykorzystaniu dodatku pulpy karobowej rzędu 45-56\% odnotowano nawet spadek zawartości tłuszczu, co z punktu widzenia hodowcy jest wadą (Silanikove i in., 2006). Istotnym zatem będzie zastosowanie prawidłowego udziału pulpy karobowej w diecie zwierząt gospodarskich, by uzyskać zamierzone parametry zarówno fizykochemiczne jak i organoleptyczne w produkcie finalnym. 


\section{Wartość odżywcza i prozdrowotna karobu}

Karob stanowić może bardzo cenny surowiec także pod względem odżywczym. Najistotniejszymi składnikami bioaktywnymi szarańczynu są liczne związki przeciwutleniające, które występują zarówno w strąkach, nasionach, łupinach nasion oraz liściach drzewa karobowego (Rtibi i in., 2017). Antyoksydanty szarańczynu zostały wymienione w podrozdziale „skład karobu”, a właściwości przeciwutleniające zostały potwierdzone badaniami własnymi oraz innymi (Albertos i in., 2015; Biernacka i in., 2017; Rtibi i in., 2017; Turfani i in., 2017; Ghanemi i in., 2017).

Rola antyoksydantów w regulacji zdrowia ludzkiego została bardzo szeroko przebadana i opisana w literaturze. Ich podstawową rolą jest dezaktywowanie wolnych rodników, do których zalicza się przede wszystkim reaktywne formy tlenu. Proszek karobowy oraz inne części drzewa karobowego charakteryzują się wysokim stężeniem polifenoli, które z powodzeniem mogą zostać wykorzystane nawet w przypadku chemoprewencji raka jelita grubego. Problem ten stanowi istotny czynnik do poprawy stanu zdrowia publicznego. Ghanemi i in. przeprowadzili doświadczenie, w którym wykazali, że ekstrakt uzyskany z liści karobu może stanowić skuteczny produkt $\mathrm{w}$ prewencji i zahamowaniu wzrostu guzów w jelicie grubym (liście karobu zawierają kwas galusowy i m-kumarowy). Autorzy odnotowali również efekt synergistyczny owych polifenoli, wpływający na skuteczność przeciwutleniająca. Zasugerowano, że udowodnione działanie $\mathrm{w}$ badaniach in vitro i in vivo powinno stanowić podstawę do zastosowania karobu w produkcji żywności funkcjonalnej, która miałaby ograniczać ryzyko raka jelita grubego w populacji (Ghanemi i in., 2017). Innymi funkcjami polifenoli może być prewencja chorób sercowo-naczyniowych. Choroby o tym podłożu są odpowiedzialne za największą ilość zgonów w krajach wysokorozwiniętych (Lopez i in., 2006). Najważniejszym oddziaływaniem jest ograniczenie zmian miażdżycowych poprzez zahamowanie utleniania frakcji LDL cholesterolu (Węglarz i in., 2011).

Drugą grupą związków, które odgrywają ogromną rolę w mączce karobowej jest błonnik pokarmowy, który definiowany jest jako „chemicznie niejednorodne składniki pochodzące z roślin spożywanych przez człowieka, a także węglowodany, które nie ulegają trawieniu $\mathrm{i}$ wchłanianiu $\mathrm{w}$ jelicie cienkim, natomiast ulegają pełnej lub częściowej fermentacji w jelicie grubym" (Bienkiewicz i in., 2015). Definicja ta nie jest jednak ostateczna, ponieważ ilość substancji zaliczana do błonnika pokarmowego stale rośnie (Jarosz (red.) i in., 2012). Mączka szarańczynu zawiera aż 27-50\% błonnika pokarmowego (Rtibi i in., 2017). Pokarm bogaty w błonnik charakteryzuje się wysoką lepkością, dzięki czemu dłużej przebywa w żołądku i poprawia to efektywność wchłaniania oraz trawienia. Dodatkowo, frakcja rozpuszczalna w wodzie tworzy swoistą barierę dla enzymów hydrolitycznych, co w konsekwencji prowadzi do spowolnienia trawienia. Posiłki, które zostały wzbogacone w błonnik pokarmowy, mimo iż charakteryzują się niższą gęstością energetyczną, wywołują to samo uczucie sytości. Pozwala to zmniejszyć wartość energetyczną posiłku i tym samym może stanowić dobre narzędzie do walki z otyłością.

Normy żywieniowe Instytutu Żywności i Żywienia w Polsce wskazują, iż dobowe spożycie błonnika pokarmowego dla osoby dorosłej powinno wynosić powyżej $25 \mathrm{~g}$ na dobę (Jarosz (red.) i in., 2012). Wiele badań wskazuje, że spożycie błonnika jest odwrotnie proporcjonalne do liczby zgonów spowodowanych chorobami układu sercowonaczyniowego. Zwiazane jest to $\mathrm{z}$ oddziaływaniem błonnika na redukcję redukcji czynników będących prekursorami chorób układu krążenia. Zaliczyć do nich należy 
nadciśnienie tętnicze, wysokie stężenie cholesterolu we krwi, a także obecności biomarkerów odpowiedzialnych za stany zapalne w organizmie (Bienkiewicz i in., 2015). Kwestią dyskusyjną pozostaje, czy błonnik pokarmowy może mieć znaczenie przy zmniejszaniu rozwoju nowotworów. Potencjalne antynowotworowe oddziaływanie błonnika może wynikać ze stymulacji produkcji nowych komórek, zapobieganiu atrofii nabłonka, poprawianiu pasażu treści pokarmowych przez jelita, a także zdolności do fermentacji. Ostatnie zjawisko przyczynia się do powstania krótkołańcuchowych kwasów thuszczowych (Bienkiewicz i in., 2015).

Błonnik pokarmowy pełni także istotną rolę w zmaganiach z cukrzycą, która dotyka coraz większą część populacji. Oddziaływanie te polega na obniżaniu poposiłkowego stężenia glukozy we krwi i/lub obniżaniu poziomu insuliny. Liczne badania naukowe potwierdzają ten korzystny wpływ błonnika pokarmowego w cukrzycy typu II (Bienkiewicz i in. 2015; Jarosz (red.) i in., 2012).

Dodatkowymi zaletami karobu jest to, że będąc substytutem kakao, zawiera bardzo małe ilości tłuszczu oraz jest wolny od substancji antyodżywczych jakimi są teobromina i kofeina. Wielokrotnie wskazuje się również, że szarańczyn może być alternatywą dla osób u których występuje alergia na kakao.

\section{Podsumowanie}

Karob stanowi surowiec, który znajduje bardzo szerokie zastosowanie w przemyśle spożywczym. Ponadto, charakteryzuje się bardzo wysoką zawartością składników bioaktywnych o funkcjach prozdrowotnych, do których zaliczyć należy przede wszystkim przeciwutleniacze oraz błonnik pokarmowy. Obie grupy tych związków zostały szczegółowo przebadane i jednoznacznie potwierdzono ich korzystny wpływ na zdrowie ludzkie. Mimo tak wielu zalet, mączka chleba świętojańskiego jest bardzo słabo znanym produktem na polskim rynku. Dostępny jest w głównej mierze, w sklepach z żywnością ekologiczną i najczęściej sprzedawany jest jedynie w wariancie ekologicznym. Ze względu na swoje charakterystyczne cechy organoleptyczne, karob wielokrotnie wykorzystywany jest jako składnik poprawiający smak produktu bądź jako substytut kakao. Ponadto, w krajach gdzie prowadzi się uprawę drzewa karobowego, mączka chleba świętojańskiego bardzo często stanowi podstawowy surowiec do produkcji słodyczy.

W świetle wielu zastosowań i ogromnego potencjału karobu, atrakcyjnym wydaje się szersze wprowadzenie produktu na polski rynek. Producenci zdają się wykorzystywać przede wszystkim mączkę chleba świętojańskiego jak zagęstnik, stabilizator oraz jako źródło przeciwutleniaczy, które mają chronić inny produkt. Efekty wykorzystania karobu jako składnika makaronu z semoliny oraz wykorzystanie łupin nasion karobowych jako skutecznego przeciwutleniacza przy produkcji rozdrobnionych ryb $\mathrm{np}$. w konserwach, są obiecujące. Konsumenci nie stwierdzili wyraźnych różnic ani w smaku ani w barwie produktów finalnych. Parametry fizykochemiczne owych wyrobów były jednak zdecydowanie lepsze. Ze względu na bardzo korzystny skład karobu, zasadnym wydaje się próba wytworzenia jak największej ilości produktów funkcjonalnych $\mathrm{z}$ jego zastosowaniem. Możliwe, że przy odpowiedniej technologii uda się wyprodukować stosunkowo niedrogie, funkcjonalne słodycze, co z pewnością ucieszyłoby konsumentów od najmłodszych po najstarszych. 


\section{Bibliografia}

Albertos, I., Jaime, I., María Diez, A., González-Arnaiz, L., Rico, D. (2015). Carob Seed Peel as Natural Antioxidant in Minced and Refrigerated $\left(4^{\circ} \mathrm{C}\right)$ Atlantic Horse Mackerel (Trachurus Trachurus). LWT - Food Science and Technology, 64(2), 650-656.

Benković, M., Belščak-Cvitanović, A., Bauman, I., Komes, D., Srečec, S. (2017). Flow Properties and Chemical Composition of Carob (Ceratonia Siliqua L.) Flours as Related to Particle Size and Seed Presence. Food Research International, 100(2), 211-218.

Bienkiewicz, M., Bator, E., Bronkowska, M. (2015). Błonnik pokarmowy i jego znaczenie w profilaktyce zdrowotnej (Dietary fiber and its importance in health promotion), Problemy Higieny $i$ Epidemiologii, 96(1), 57-63.

Biernacka, B., Dziki, D., Gawlik-Dziki, U., Różyło, R., Siastała, M. (2017). Physical, Sensorial, and Antioxidant Properties of Common Wheat Pasta Enriched with Carob Fiber. LWT - Food Science and Technology, 77, 186-192.

Biner, B., Gubbuk, H., Karhan, M., Aksu, M., Pekmezci, M. (2007). Sugar Profiles of the Pods of Cultivated and Wild Types of Carob Bean (Ceratonia Siliqua L.) in Turkey. Food Chemistry, 100, 1453-1455.

Durazzo, A., Turfani, V., Narducci, V., Azzini, E., Maiani, G., Carcea, M. (2014). Nutritional Characterisation and Bioactive Components of Commercial Carobs Flours. Food Chemistry, 153, 109-113.

Dyrektywa 2000/36/WE Parlamentu Europejskiego i Rady z dnia 23 czerwca 2000 r. odnosząca się do wyrobów kakaowych i czekoladowych przeznaczonych do spożycia przez ludzi (Directive 2000/36/EC of the European Parliament and of the Council of 23 June 2000 relating to cocoa and chocolate products intended for human consumption). Dz. U. L 197, 03/08/2000 P. 0019 - 0025.

Ghanemi, F.Z., Belarbi, M., Fluckinger, A., Nani, A., Dumont A., De Rosny, Ch., Aboura, I., Khan, A.S., Murtaza, B., Benammar, Ch., Lahfa, B.F., Patoli, D., Delmas, D., Rebe, C., Aprtoh, L., Khan, N.A., Ghiringhelli, F., Rialland, M., Hichami, A. (2017). Carob Leaf Polyphenols Trigger Intrinsic Apoptotic Pathway and Induce Cell Cycle Arrest in Colon Cancer Cells. Journal of Functional Foods, 33, 112-121.

Gravador, R.S., Luciano, G., Jongberg, S., Bognanno, M., Scerra, M., Andersen, M.L., Lund, M.N., Priolo, A. (2015). Fatty Acids and Oxidative Stability of Meat from Lambs Fed Carob-Containing Diets. Food Chemistry, 182, 27-34

https://www.icco.org/.

Jarosz, M. (red.) (2012). Normy żywienia dla populacji polskiej - nowelizacja (Nutritional norms for the Polish population - amendment), İ̇Ż, Warszawa.

Kowalska, J., Bzducha, A., Drewiaka, D., Kopańska, K., Nitek, A. (2008). Ocena autentyczności wybranych czekolad (Assessing the authenticity of some selected chocolates), ŻYWNOŚĆ. Nauka. Technologia. Jakość, 4(59), 74-79.

Lopez, A.D., Mathers, C.D. (2006). Measuring the Global Burden of Disease and Epidemiological Transitions: 2002-2030. Annals of Tropical Medicine \& Parasitology, 100(5-6), 481-499.

Mitka, K., Nowak, K. (2007). Mączka chleba świętojańskiego (E 410) - coraz częściej stosowany dodatek do środków spożywczych. Przemyst Fermentacyjny i Owocowo-Warzywny, 7-8, 49-52.

Owen, R., Haubner, R., Hull, W.E., Erben, G., Spiegelharder, B., Bartsch, H, Haber, B. (2003). Isolation and Structure Elucidation of the Major Individual Polyphenols in Carob Fibre. Food and Chemical Toxicology, 41(12), 1727-1738.

PN-EN ISO 23275-1 2009P

Rozporządzenie Ministra Zdrowia z dnia 22 listopada 2010 r. w sprawie dozwolonych substancji dodatkowych (Regulation of the Minister of Health of November 22, 2010 on the permitted additional substances). Dz. U. 232, poz. 1525

Rtibi, K, Selmi, S., Grami, D., Amri, M., Eto, B., El-benna, J., Sebai, H., Marzouki, L. (2017). Chemical Constituents and Pharmacological Actions of Carob Pods and Leaves (Ceratonia Siliqua L.) on the Gastrointestinal Tract: A Review. Biomedicine and Pharmacotherapy, 93, 522-528.

$\mathrm{S} \square$ czyk, Ł., Świeca, M., Gawlik-Dziki, U. (2016). Effect of Carob (Ceratonia Siliqua L.) Flour on the Antioxidant Potential, Nutritional Quality, and Sensory Characteristics of Fortified Durum Wheat Pasta. Food Chemistry, 194, 637-642.

Silanikove, N. Landau, S., Or, D., Kababya, D., Bruckental, I., Nitsan, Z. (2006). Analytical Approach and Effects of Condensed Tannins in Carob Pods (Ceratonia Siliqua) on Feed Intake, Digestive and Metabolic Responses of Kids. Livestock Science, 99(1), 29-38. 


\section{Kłobukowski F., Śmiechowska M., Skotnicka M.}

Turfani, V., Narducci, V., Durazzo, A., Galli, V., Carcea, M. (2017). Technological, Nutritional and Functional Properties of Wheat Bread Enriched with Lentil or Carob Flours. LWT - Food Science and Technology, 78, 361-366.

UOKiK (2010). Informacja z kontroli jakości i oznakowania wyrobów czekoladowych i wyrobów w polewie czekoladowej (Information on quality control and labeling of chocolate products and chocolate coated products), UOKiK Warszawa.

Węglarz, M., Kubica, A., Sinkiewicz, W. (2011). Znaczenie czekolady w prewencji chorób sercowonaczyniowych (The role of chocolate in preventing cardiovascular diseases), Folia Cardiologica Excerpta, $6(2), 127-134$

Do cytowania / For citation:

Kłobukowski F., Śmiechowska M., Skotnicka M. (2018). Możliwości wykorzystania karobu (Ceratonia siliqua) w sektorze żywnościowym i żywieniowym. Problemy Rolnictwa Światowego, 18(2), 140-148; DOI: 10.22630/PRS.2018.18.2.41

Kłobukowski F., Śmiechowska M., Skotnicka M. (2018). Possibilities of utilizing carob (Ceratonia siliqua) in food industry and nutrition (in Polish). Problems of World Agriculture, 18(2), 140-148; DOI: $10.22630 / P R S .2018 .18 .2 .41$ 